\title{
Preface: Natural hazard impacts on technological systems and infrastructures
}

\author{
Elena Petrova ${ }^{1}$ and Maria Bostenaru Dan ${ }^{2}$ \\ ${ }^{1}$ Faculty of Geography, Lomonosov Moscow State University, Moscow, 119991, Russia \\ ${ }^{2}$ Faculty of Urban Planning, Ion Mincu University of Architecture and Urbanism, Bucharest, 010014, Romania
}

Correspondence: Elena Petrova (epgeo@mail.ru)

Published: 5 October 2020

\section{Introduction}

Critical infrastructures and other technological systems such as transportation systems, telecommunication networks, power lines, pipelines, and reservoirs are at risk of natural hazards (e.g., earthquakes, floods, landslides) in many urban and rural areas worldwide. A key to the safe and affordable operations of these types of infrastructure is an in-depth knowledge of their exposure and vulnerability to natural hazards and the impact of damage experienced either locally or across the network. A fundamental understanding of hazard and risk involves (a) systematic identification, monitoring, and mapping of potential infrastructure exposure, (b) integrated assessment of impact as a result of damage, repair, and/or mitigation, (c) indirect losses from infrastructure disruption and synergistic effects, and (d) consideration of interactions between hazards and/or cascades of hazards.

The special issue (SI) "Natural hazard impacts on technological systems and infrastructures" was organized in the aftermath of two sessions of the same name at the European Geosciences Union (EGU) general assemblies of 2018 and 2019 held in Vienna, Austria. The special issue aims at raising awareness of this topical and increasing problem by summarizing and analyzing relationships between natural events and technological accidents, collecting experiences, and finding out new methods of assessing the vulnerability of technological and infrastructure objects to natural hazards. This SI includes contributions with a focus on natural hazard risk assessment for critical infrastructure and technological systems, as well as a compilation of databases that record the impacts and elements at risk. The SI is dedicated to contributions with national, regional, and local perspective, covering a wide range of different geographic regions.
In Sect. 2 of this preface, there is a brief overview of each contribution to the special issue. This is followed by a summary of the research in Sect. 3 .

\section{Research contributions}

Critical infrastructures and other technological systems are exposed to various types of natural hazards from geophysical to hydrometeorological and others. Contributions of the SI consider wide variety of natural hazards and their impacts on different types of infrastructure.

Jeong et al. (2019) study freezing precipitation and extreme ice loads that can lead to severe damage and the failure of buildings and infrastructure. Fluixá-Sanmartín et al. (2019) assess the impacts of climate change on dam safety under hydrological scenarios. Chen et al. (2019) evaluate the influence of land use and land cover change on landslide susceptibility. Braud et al. (2020) study runoff hazards in the railway context. Williams et al. (2020) assess the vulnerability of transportation to tsunami. Toma-Danila et al. (2020) analyze seismic hazards and Mossoux et al. (2019) volcanic hazards to road networks. Petrova (2020) considers natural hazard impacts of all types on the transportation infrastructure.

The study areas vary from national and interregional scales in North America (Jeong et al., 2019), Brazil (Sayão et al., 2020), Chili, Japan (Williams et al., 2020), and the Russian Federation (Frolova et al., 2020; Petrova, 2020) to regional and local scales in Normandy, France (Braud et al., 2020), the province of Salamanca in Spain (Fluixá-Sanmartín et al., 2019), Bucharest in Romania (Toma-Danila et al., 2020), Hubei Province in China (Chen et al., 2019), and Ngazidja Island, NW of Madagascar (Mossoux et al., 2019). 
The study by Jeong et al. (2019) investigates projected changes to extreme ice loads, which are used to design buildings and infrastructure in North America (NA), for future periods with different levels of global mean temperature change above the baseline 1986-2016 level. Atmospheric ice accretion caused by freezing precipitation during ice storms can affect many economic sectors such as wind energy generation, urban functioning, communication structures, the forestry sector, and electrical infrastructure. The authors use a large ensemble of Canadian regional climate model simulations (Arora et al., 2011; Fyfe et al., 2017). The model projects an increase in future design ice loads for most of northern NA and decreases for most of southern NA and some northeastern coastal regions. These changes are mainly caused by regional increases in future upper-level and surface temperatures associated with global warming and are additionally affected by changes in future precipitation intensity and surface wind speed. Increases in ice accretion for latitudes higher than $40^{\circ} \mathrm{N}$ are substantial and would have clear implications for future facilities and infrastructure design.

Fluixá-Sanmartín et al. (2019) present a comprehensive quantitative assessment of how climate change can have an affect on the failure risk of a dam. The Santa Teresa dam (province of Salamanca, Spain) is a case study. The analysis has been elaborated under hydrological scenarios in which the floods are the main loads to which the dam is subjected. A key innovative aspect of the proposed methodology is the use of a wide variety of models and data sources and their combination to assess the overall impact of climate change on the dam's safety. The analysis integrates various projected effects acting on each component of the risk, from the input hydrology to the consequences of the outflow hydrograph. Among these components, mainly four have been identified as susceptible to being altered: previous pool levels in the reservoir, spillway gate and bottom outlet performance, floods entering the reservoir, and social consequences are used to compute the social risk. The results of 21 regional climate models encompassing three different Representative Concentration Pathways (IPCC, 2013; Moss et al., 2010) have been used to calculate the risk evolution of the dam until the end of the 21 st century.

The study by Williams et al. (2020) represents the first attempt at developing tsunami fragility functions for roads and bridges based on empirical data from two recent tsunami events. Combined survey and remotely sensed data for the 2011 Tōhoku earthquake and tsunami, Japan, and postevent field survey data from the 2015 Illapel earthquake and tsunami, Chile, are analyzed. The authors provide a suite of observations on the influence of tsunami inundation depth, road-use type, culverts, inundation distance, debris, and coastal topography. Fragility functions are developed for roads, which consider inundation depth, road-use type, and coastal topography, and for bridges, which consider only inundation depth above deck base height. The empirical road and bridge fragility functions, developed in this study, con- sider a range of damage levels. This suite of synthesized functions is applicable to a variety of exposure and attribute types for use in global tsunami impact assessments to inform resilience and mitigation strategies.

The paper by Braud et al. (2020) presents a methodology to compare maps of the susceptibility of a territory to surface runoff and proxy data of impacts related to runoff. This method accounts for the hazard level, the vulnerability of the study area, and possible mitigation actions taken to reduce the risk. The paper focuses on one kind of proxy data, which is localized runoff-related impacts such as the impact on transport (railway) networks. The objective of the paper is to propose a methodology to use these proxy data for the evaluation of a nonquantitative method of runoff hazard mapping, such as the IRIP (indicator of intense pluvial runoff) method. The evaluation method is assessed using a comprehensive database of runoff-related impacts collected on an $80 \mathrm{~km}$ railway line between Rouen and Le Havre in Normandy (north of France) and covering the period from 1903 to 2017. The data set also allowed them to assess the relevance of the IRIP model for runoff hazard mapping on a wide area in the railway context.

The paper by Petrova (2020) considers the impacts of natural hazards of various types on transport infrastructure in the Russian Federation. The author's database of technological and natural-technological accidents is used as a source of data for the analyses. Contributions of natural factors to road, railway, air, and water transport accidents and failures are assessed. The total risk of transport accidents and traffic disruptions triggered by adverse and hazardous natural impacts, as well as the risk of road and railway accidents and disruptions to these most popular modes of transport, is assessed at the level of Russian federal regions. The concept of an emergency situation is used to measure risk. As an indicator of risk, the average frequency of occurrence of transport accidents and traffic disruptions triggered by natural hazard impacts which have led to emergency situations of different scales and severity was used. All the federal regions were divided into groups by their risk levels of road and railway accidents, as well as the total risk of transport accidents and traffic disruptions. In each case, the risk level was determined in comparison to the average value of the corresponding indicator for Russia.

Like the paper by Petrova (2020), the paper by Sayão et al. (2020) also deals with a spatial database. The infrastructure considered are reservoirs, the failure of which leads to seismic consequences. In this way, the topic is important because today's discussion on renewable energy has many times exploited hydroelectric energy. The failure of dams has been a subject since the first ones in the Alps in Europe. The database is useful for research as such since it is available in a web viewer or to be replicated in other countries. Building such a database is an attempt at information visualization, including developing an ontology of the database in UML (Unified Modeling Language), which belongs today to the 
digital humanities. Since more involvement of the humanities is needed in natural disaster research and the topic of the special issue builds on the "natural hazards and society" section of the EGU, the paper is a good enrichment of the SI.

Frolova et al. (2020) consider instead the application of an impact database for the example of Russia, as in Petrova (2020). The database is available upon special request for international projects, thus constituting an infrastructure itself for later projects. The paper presents statistics of the database and how this database can be useful for artificial intelligence self learning in order to prepare for emergencies. A companion paper has been published in the NHESS Special Issue "Natural hazards and technological disasters" (Petrova and Krausmann, 2011).

Toma-Danila et al. (2020) deal with earthquake effects on transportation networks. Secondary hazards are also taken into account. The case study to exemplify the network analysis methodology is Bucharest, the capital of Romania, and the road network in particular is considered. In the 1977 earthquake, major life and property losses were recorded in Bucharest, making it a capital in Europe with a significant seismic risk. The vulnerability of the road network is important in disaster management, in particular in the emergency response phase when deploying search and rescue teams and accessing hospitals. For this reason, the whole network of such a large city is a suitable case study. The analysis of the vulnerability of the transportation network is done using a geographic information system (GIS). The deterministic simulation is expanded to general terms using a Monte Carlo simulation. The Network-risk toolbox for ArcGIS desktop is made available for researchers in order for them to be able to replicate the study.

Mossoux et al. (2019) also deal with the road network. A hazard mapping considering road segments is proposed. Each road segment is assessed depending on its importance to the whole infrastructure before and after a disruption through a volcanic event. Two metrics are considered: road accessibility risk (road segments to allow access to the closest infrastructure) and users' path vulnerability (considering rerouting). The case study is Ngazidja Island (Union of the Comoros), a volcanic island in SE Africa, NW of Madagascar. The paper discusses how disaster management can intervene in this case by highlighting the most important road segments, but it also proposes changes through new segments or new infrastructure (e.g., hospitals).

Chen et al. (2019) study the impact of engineering activities on natural hazards, in this case landslides, over more than 2 decades, during which human engineering increased. The two landslides considered are from 2007 and 2012. Other factors relying on geography and geology and connected to the river bed are also considered. In this way, the paper is relevant in addressing the impacts of natural hazards on urban and rural areas through land use policies. It is a nonstructural measure to mitigate hazards for which this paper is an argument. A case study from China is provided, involving both remote sensing and satellite imagery and field work at eye level. Also in this case, networks are used (neural network self learning), along with object-oriented programming for image classification. For probabilistic assessment, regression is employed.

\section{Summary}

Projected changes to design ice thickness as quantified in the study by Jeong et al. (2019) will be useful information for the development of climate-resilient design standards, codes, and guides for buildings and infrastructure. Caution in designing for ice loads at latitudes higher than $40^{\circ} \mathrm{N}$ is warranted due to projected increases in extreme ice thickness. As the results show, it is important to examine changes in the future probability of extreme ice loads occurring simultaneously with extreme wind load in northern NA because the compounding effect may lead to an increase in load larger than the increase in ice load or wind load alone.

The methodology proposed by Fluixá-Sanmartín et al. (2019) allows a detailed quantification of the effect of climate change on dam safety, which is one of the main concerns of the managers and technicians of this critical infrastructure for water supply and energy production worldwide. It can serve as a useful guide for dam owners and dam safety practitioners in the analysis of other study cases by encompassing different models and data sources. This would eventually allow a more efficient planning of dam safety investments in the long term and even the adaptation of existing dam exploitation rules. Sayão et al. (2020) also deal with dam safety but from a seismic hazard point of view. They introduce the issue of the visualization of databases, while Petrova (2020) and Frolova et al. (2020) also deal with databases of natural hazard impacts on infrastructure, providing useful tools for further research.

Williams et al. (2020) conclude that the fragility functions show a trend of lower tsunami vulnerability (through lower probabilities of reaching or exceeding a given damage level) for road-use categories of potentially higher construction standards; bridges are more vulnerable to the impacts of tsunamis than roads; however, bridges are better designed to withstand the forces of tsunami loading and have a lower level of vulnerability at all hazard intensities (inundation depth) compared to buildings; culverts represent particularly vulnerable sections of roads. The topographic setting is also shown to affect the vulnerability of transportation assets in a tsunami.

Braud et al. (2020) proposed the methodology that is robust, relevant, and generic enough to evaluate a nonquantitative method of runoff hazard mapping using localized runoffrelated proxy data. The results from their case study confirm that the susceptibility maps produced by the IRIP model provide relevant information related to runoff and that they can 
be used to design risk management strategies, as illustrated in the railway context.

Among all the identified types of natural hazards in the study by Petrova (2020), hydrometeorological hazards such as heavy snowfalls and rains, floods, and ice phenomena, as well as dangerous exogenous slope processes including snow avalanches, debris flows, landslides, and rock falls, were revealed as having the largest contributions to transport accidents and disruptions. The most dangerous is the combination of heavy precipitations and strong winds. Regional differences in the risk of transport accidents between Russian federal regions were found and analyzed.

Toma-Danila et al. (2020) and Mossoux et al. (2019) deal with the vulnerability of the transport infrastructure and, more precisely, the road network. This is important in emergency management in the case of a natural disaster (earthquake and volcanic eruption) in order to access such infrastructure as hospitals. Chen et al. (2019) consider the effects of human engineering in increasing landslide susceptibility and effects on infrastructure, providing case studies of two landslides in the vicinity of bridges. If the analysis of transport infrastructure may lead to better planning by providing new road segments and new infrastructure, then in the case of human engineering, land use change, a nonstructural measure, can also be undertaken to provide better land use through regional plans.

Looking at the lessons learned from the database and information visualization papers which promote the conversion of data to information - and thus the digital humanities - as well as at the urban, regional, and mobility plans which are necessary to better manage transportation networks and human engineering activities, how other disciplines can contribute to natural hazard research is also highlighted.

Special issue statement. This article is part of the special issue "Natural hazard impacts on technological systems and infrastructures". It is a result of the EGU General Assembly 2018, Vienna, Austria, 8-13 April 2018, and the EGU General Assembly 2019, Vienna, Austria, 7-12 April 2019.

Acknowledgements. We acknowledge all the authors and reviewers who contributed to this special issue.

Financial support. This research has been supported by the Lomonosov Moscow State University (grant no. I.7 AAAA-A16116032810093-2, "Mapping, modeling and risk assessment of dangerous natural processes").

\section{References}

Arora, V. K., Scinocca, J. F., Boer, G. J., Christian, J. R., Denman, K. L., Flato, G. M., Kharin, V. V., Lee, W. G., and Merryfield, W. J.: Carbon emission limits required to satisfy future representative concentration pathways of greenhouse gases, Geophys. Res. Lett., 38, L05805, https://doi.org/10.1029/2010GL046270, 2011.

Braud, I., Lagadec, L.-R., Moulin, L., Chazelle, B., and Breil, P.: A method to use proxy data of runoff-related impacts for the evaluation of a model mapping intense storm runoff hazard: application to the railway context, Nat. Hazards Earth Syst. Sci., 20, 947-966, https://doi.org/10.5194/nhess-20-947-2020, 2020.

Chen, L., Guo, Z., Yin, K., Shrestha, D. P., and Jin, S.: The influence of land use and land cover change on landslide susceptibility: a case study in Zhushan Town, Xuan'en County (Hubei, China), Nat. Hazards Earth Syst. Sci., 19, 2207-2228, https://doi.org/10.5194/nhess-19-2207-2019, 2019.

Fluixá-Sanmartín, J., Morales-Torres, A., Escuder-Bueno, I., and Paredes-Arquiola, J.: Quantification of climate change impact on dam failure risk under hydrological scenarios: a case study from a Spanish dam, Nat. Hazards Earth Syst. Sci., 19, 2117-2139, https://doi.org/10.5194/nhess-19-2117-2019, 2019.

Frolova, N., Larionov, V., Bonnin, J., Suchshev, S., Ugarov, A., and Malaeva, N.: Impact database application for natural and technological risk management, Nat. Hazards Earth Syst. Sci., 20, 95-106, https://doi.org/10.5194/nhess-20-95-2020, 2020.

Fyfe, J. C., Derksen, C., Mudryk, L., Flato, G. M., Santer, B. D., Swart, N. C., Molotch, N. P., Zhang, X., Wan, H., Arora, V. K., Sciocca, J., and Jiao, Y.: Large near-term projected snowpack loss over the western United States, Nat. Commun., 8, 14996, https://doi.org/10.1029/2010GL046270, 2017.

IPCC: Climate Change 2013: The Physical Science Basis, in: Contribution of Working Group I to the Fifth Assessment Report of the Intergovernmental Panel on Climate Change, Cambridge University Press, Cambridge, UK, and New York, NY, USA, 2013.

Jeong, D. I., Cannon, A. J., and Zhang, X.: Projected changes to extreme freezing precipitation and design ice loads over North America based on a large ensemble of Canadian regional climate model simulations, Nat. Hazards Earth Syst. Sci., 19, 857-872, https://doi.org/10.5194/nhess-19-857-2019, 2019.

Moss, R. H., Edmonds, J. A., Hibbard, K. A., Manning, M. R., Rose, S. K., van Vuuren, D. P., Carter, T. R., Emori, S., Kainuma, M., Kram, T., Meehl, G. A., Mitchell, J. F. B., Nakicenovic, N., Riahi, K., Smith, S. J., Stouffer, R. J., Thomson, A. M., Weyant, J. P., and Wilbanks, T. J.: The next generation of scenarios for climate change research and assessment, Nature, 463, 747-756, https://doi.org/10.1038/nature08823, 2010.

Mossoux, S., Kervyn, M., and Canters, F.: Assessing the impact of road segment obstruction on accessibility of critical services in case of a hazard, Nat. Hazards Earth Syst. Sci., 19, 1251-1263, https://doi.org/10.5194/nhess-19-1251-2019, 2019.

Petrova, E.: Natural hazard impacts on transport infrastructure in Russia, Nat. Hazards Earth Syst. Sci., 20, 1969-1983, https://doi.org/10.5194/nhess-20-1969-2020, 2020.

Petrova, E. G. and Krausmann, E.: Postface "From natural hazards to technological disasters", Nat. Hazards Earth Syst. Sci., 11, 3063-3065, https://doi.org/10.5194/nhess-11-3063-2011, 2011. 
Sayão, E., França, G. S., Holanda, M., and Gonçalves, A.: Spatial database and website for reservoir-triggered seismicity in Brazil, Nat. Hazards Earth Syst. Sci., 20, 2001-2019, https://doi.org/10.5194/nhess-20-2001-2020, 2020.

Toma-Danila, D., Armas, I., and Tiganescu, A.: Network-risk: an open GIS toolbox for estimating the implications of transportation network damage due to natural hazards, tested for Bucharest, Romania, Nat. Hazards Earth Syst. Sci., 20, 14211439, https://doi.org/10.5194/nhess-20-1421-2020, 2020.
Williams, J. H., Wilson, T. M., Horspool, N., Paulik, R., Wotherspoon, L., Lane, E. M., and Hughes, M. W.: Assessing transportation vulnerability to tsunamis: utilising post-event field data from the 2011 Tōhoku tsunami, Japan, and the 2015 Illapel tsunami, Chile, Nat. Hazards Earth Syst. Sci., 20, 451-470, https://doi.org/10.5194/nhess-20-451-2020, 2020. 